\title{
Sphingosine 1-phosphate receptor 3 and RhoA signaling mediate inflammatory gene expression in astrocytes
}

Stephanie S. Dusaban ${ }^{1}$, Jerold Chun², Hugh Rosen ${ }^{3}$, Nicole H. Purcell ${ }^{1 *}$ and Joan Heller Brown ${ }^{*}$

\begin{abstract}
Background: Sphingosine 1-phosphate (S1P) signals through G protein-coupled receptors to elicit a wide range of cellular responses. In CNS injury and disease, the blood-brain barrier is compromised, causing leakage of S1P from blood into the brain. S1P can also be locally generated through the enzyme sphingosine kinase-1 (Sphk1). Our previous studies demonstrated that S1P activates inflammation in murine astrocytes. The S1P 1 receptor subtype has been most associated with CNS disease, particularly multiple sclerosis. $\mathrm{S1P}_{3}$ is most highly expressed and upregulated on astrocytes, however, thus we explored the involvement of this receptor in inflammatory astrocytic responses.
\end{abstract}

Methods: Astrocytes isolated from wild-type $(\mathrm{WT})$ or $\mathrm{S}_{\mathrm{P}} \mathrm{P}_{3}$ knockout $(\mathrm{KO})$ mice were treated with $\mathrm{S}_{\mathrm{P}}$ selective drugs or transfected with short interfering RNA to determine which receptor subtypes mediate S1P-stimulated inflammatory responses. Interleukin-6 (IL-6), and vascular endothelial growth factor A (VEGFa) messenger RNA (mRNA) and cyclooxygenase-2 (COX-2) mRNA and protein were assessed by q-PCR and Western blotting. Activation of RhoA was measured using SRE.L luciferase and RhoA implicated in S1P signaling by knockdown of $\mathrm{Ga}_{12 / 13}$ proteins or by inhibiting RhoA activation with C3 exoenzyme. Inflammation was simulated by in vitro scratch injury of cultured astrocytes.

Results: $\mathrm{S}_{1} \mathrm{P}_{3}$ was highly expressed in astrocytes and further upregulated in response to simulated inflammation. Studies using $\mathrm{S} \mathrm{P}_{3}$ knockdown and $\mathrm{S}_{1} \mathrm{P}_{3} \mathrm{KO}$ astrocytes demonstrated that $\mathrm{S}_{\mathrm{P}} \mathrm{P}_{3}$ mediates activation of RhoA and induction of COX-2, IL-6, and VEGFa mRNA, with some contribution from S1P. S1P induces expression of all of these genes through coupling to the $\mathrm{Ga}_{12 / 13}$ proteins which activate RhoA. Studies using $\mathrm{S} \mathrm{P}_{3}$ selective agonists/antagonists as well as Fingolimod (FTY720) confirmed that stimulation of $\mathrm{S}_{1} \mathrm{P}_{3}$ induces COX-2 expression in astrocytes. Simulated inflammation increased expression of Sphk1 and consequently activated $\mathrm{S}_{\mathrm{P}} \mathrm{P}_{3}$, demonstrating an autocrine pathway through which S1P is formed and released from astrocytes to regulate COX-2 expression.

Conclusions: $\mathrm{S}_{\mathrm{P}_{3}}$, through its ability to activate RhoA and its upregulation in astrocytes, plays a unique role in inducing inflammatory responses and should be considered as a potentially important therapeutic target for CNS disease progression.

Keywords: Astrocytes, Central nervous system, Inflammation, RhoA, S1P, S1P 3

\footnotetext{
* Correspondence: npurcell@ucsd.edu; jhbrown@ucsd.edu

${ }^{1}$ Department of Pharmacology, School of Medicine, University of California San Diego, 9500 Gilman Drive, Biomedical Sciences Building Room 3024, La Jolla, CA 92093-0636, USA

Full list of author information is available at the end of the article
} 


\section{Background}

Sphingosine 1-phosphate (S1P) is a bioactive lipid and G protein-coupled receptor (GPCR) ligand formed within the brain from sphingomyelin and is also present at high levels in blood where it is bound to lipoproteins and stored in erythrocytes [1-5]. There are five S1P receptor subtypes [6, 7] with $\mathrm{S}_{1} \mathrm{P}_{1}, \mathrm{~S}_{1} \mathrm{P}_{2}, \mathrm{~S}_{1} \mathrm{P}_{3}$, and $\mathrm{S}_{\mathrm{P}} \mathrm{P}_{5}$ (and in some reports $\mathrm{S} \mathrm{P}_{4}$ ) expressed in the CNS [8-13]. Astrocytes are activated in response to CNS injury and diseases like multiple sclerosis (MS) and undergo astrogliosis characterized by increases in proliferation, hypertrophy, and glial fibrillary acidic protein (GFAP) expression [14-20]. S1P induces astrogliosis when injected into the brain as evidenced by increases in GFAP expression and astrocyte proliferation [21-23]. The importance of S1P receptors in disease is highlighted by the widespread acceptance of Fingolimod (FTY720; Gilenya) as a first line oral drug to treat MS [2427]. Phosphorylated fingolimod functions as an S1P analogue that blocks lymphocyte egress through functional inhibition of $\mathrm{S}_{1} \mathrm{P}_{1}$ signaling $[28,29]$. Its efficacy in the EAE mouse model of MS has also been linked to signaling through $\mathrm{S} 1 \mathrm{P}_{1}$ on astrocytes [30].

The predominant S1P receptor subtype detected by quantitative-PCR (q-PCR) in cortical astrocytes is $\mathrm{S}_{1} \mathrm{P}_{3}$, although $\mathrm{S}_{1} \mathrm{P}_{1}$ is also expressed on astrocytes from rat and mouse brain $[8,12,31]$. The potential importance of $\mathrm{S} \mathrm{P}_{3}$ signaling in astrocytes is suggested by the finding that this receptor is upregulated in MS lesions and in response to inflammatory stimuli [32-34]. In a mouse model of Sandhoff disease characterized by neuronal death and astrocyte proliferation, deletion of $\mathrm{S}_{3} \mathrm{P}_{3}$, along with the enzyme sphingosine kinase (Sphk) which catalyzes the synthesis of S1P, decreased astrogliosis and disease severity [35]. Importantly, whereas $\mathrm{S}_{1} \mathrm{P}_{1}$ exclusively couples to the $\mathrm{G}$ protein $\mathrm{G} \alpha_{\mathrm{i}}$, $\mathrm{S} \mathrm{P}_{3}$ couples promiscuously and its coupling to $\mathrm{G \alpha}_{12 / 13}$ activates the small G-protein RhoA [36-38]. Previous work from our laboratory documented the importance of RhoA activation in inducing astrocyte proliferation, gene expression, and inflammation in response to stimulation of GPCRs for thrombin and S1P [39-44].

Here, we ask whether stimulation of the $\mathrm{S}_{1} \mathrm{P}_{3}$ receptor on astrocytes activates RhoA, is responsible for inflammatory gene expression, or can be locally engaged by endogenously formed S1P in an in vitro model of neuroinflammation. We demonstrate that $\mathrm{S}_{1} \mathrm{P}_{3}$, and not $\mathrm{S}_{1} \mathrm{P}_{1}$, mediates induction of interleukin-6 (IL-6) and vascular endothelial growth factor A (VEGFa) mRNA, and cyclooxygenase-2 (COX-2) mRNA and protein in mouse astrocytes and that this occurs through S1P receptor coupling to $\mathrm{G \alpha}_{12 / 13}$ and RhoA. We also demonstrate that simulated inflammation in vitro leads to increases in expression of Sphk1 and $\mathrm{S}_{1} \mathrm{P}_{3}$ which could contribute to autocrine inflammatory astrocyte signaling.

\section{Methods}

\section{Agonists and inhibitors}

Sources were as follows: S1P was obtained from Avanti Polar Lipids. The $\mathrm{S}_{1} \mathrm{P}_{3}$ antagonist SPM-354 was synthesized and characterized as described [45]. A cell permeable botulinum C3 toxin exoenzyme, which inhibits RhoA activation, was obtained from cytoskeleton. Pertussis toxin, which ribosylates and inactivates the alpha subunit of the $G_{i}$ protein, was used to block signaling through receptor coupling to $\mathrm{G}_{\mathrm{i}}$ (Tocris Bioscience). The $\mathrm{S}_{1} \mathrm{P}_{3}$ specific agonist CYM51736 was provided by the Rosen laboratory, and the functional $\mathrm{S}_{1} \mathrm{P}_{1}$ antagonist and MS therapeutic, FTY720 (Fingolimod), and $\mathrm{S}_{2} \mathrm{P}_{2}$ antagonist JTE-013 was from Cayman Chemicals. S1P was used at $0.5 \mu \mathrm{M}$. SPM-354 was used at $5 \mu \mathrm{M}$. C3 exoenzyme was used at $0.5 \mu \mathrm{g} / \mathrm{mL}$. FTY720 was used at $100 \mathrm{nM}$. CYM-51736 was used at $10 \mu \mathrm{M}, J T E-013$ at $1 \mu \mathrm{M}$, and pertussis toxin at $100 \mathrm{ng} / \mathrm{ml}$.

\section{Animals}

All procedures were performed in accordance with NIH Guide and Care and Use of Laboratory Animals and approved by the Institutional Animal Care and Use Committee at the University of California San Diego. C57BL/6 wild-type and homozygous $\mathrm{S}_{1} \mathrm{P}_{3} \mathrm{KO}$ mice which do not exhibit any gross phenotypic abnormalities $[36,46]$ were used for astrocyte isolation.

\section{Primary culture of astrocytes}

Astrocytes were isolated from P1-P3 postnatal WT and $\mathrm{S} \mathrm{P}_{3} \mathrm{KO}$ mice [44]. Purity of astrocytes was determined to be $\sim 95 \%$ based on GFAP staining. In all experiments, WT and $\mathrm{S} \mathrm{P}_{3} \mathrm{KO}$ astrocytes were used at passage 2. Astrocytes were cultured in six-well plates, maintained in high-glucose DMEM supplemented with $10 \% \mathrm{FBS} / 2 \mathrm{mM}$ glutamine/ $100 \mathrm{units} / \mathrm{ml}$ penicillin $/ 100 \mu \mathrm{g} / \mathrm{ml}$ streptomycin (Invitrogen, Carlsbad, CA) at $37{ }^{\circ} \mathrm{C}$ in a humidified $5 \% \mathrm{CO}_{2}$-incubator. Cells used for experiments were at $80 \%$ confluency and serum-starved for 18-24 h prior to agonist treatment.

\section{siRNA transfections}

Pre-designed mouse short interfering RNA (siRNA) smartpools for $\mathrm{S}_{1} \mathrm{P}_{1}, \mathrm{~S}_{1} \mathrm{P}_{2}, \mathrm{~S}_{1} \mathrm{P}_{3}$, and control siRNA were purchased from Bioneer. Pre-designed mouse siRNA for $\mathrm{G \alpha}_{12}$, $\mathrm{G \alpha}_{13}, \mathrm{G \alpha}_{\mathrm{q}}$, and sphingosine kinase 1 were purchased from Qiagen, individual siRNAs were tested for knockdown, and the most efficient was selected for use in the current studies. Control siRNA was compared to targeted siRNAs used throughout. WT astrocytes on six-well plates were transfected using DharmaFECT-3 transfection reagent (Thermo Scientific) and $2 \mu \mathrm{M}$ siRNA in a 1:3 ratio respectively. Reagent and siRNA were incubated alone in OPTI-MEM media (Gibco) at room temperature for $10 \mathrm{~min}$ followed by mixing and incubating further for $20 \mathrm{~min}$. The siRNA/ DharmaFECT-3 mixture was added to plates containing 
fresh media. Following overnight incubation, media containing siRNA was removed, and cells were washed. Astrocytes were serum-starved for 18-24 h prior to treatment. The table below lists the predesigned or three smartpool siRNA sequences used in these studies.

\begin{tabular}{|c|c|c|}
\hline SiRNA & Sense Sequence & Antisense Sequence \\
\hline $\mathrm{S}_{\mathrm{P}} \mathrm{P}_{1}$ & $\begin{array}{l}\text { GAUAUCAUAGUCCGGCAUU } \\
\text { CCGGAGCUUUGAUUUUGCA } \\
\text { CGGACCUAUUAGCAGGCGU }\end{array}$ & $\begin{array}{l}\text { AAUGCCGGACUAUGAUAUC } \\
\text { UGCAAAAUCAAAGCUCCGG } \\
\text { ACGCCUGCUAAUAGGUCCG }\end{array}$ \\
\hline $\mathrm{S}_{\mathrm{P}} \mathrm{P}_{2}$ & $\begin{array}{l}\text { CUGUACGUCCGAAUCUACU } \\
\text { CACUUCUGGAGUGCCAGUA } \\
\text { CCUCGGUCUUUAGCCUCCU }\end{array}$ & $\begin{array}{l}\text { AGUAGAUUCGGACGUACAG } \\
\text { UACUGGCACUCCAGAAGUG } \\
\text { AGGAGGCUAAAGACCGAGG }\end{array}$ \\
\hline $\mathrm{S}_{1} \mathrm{P}_{3}$ & $\begin{array}{l}\text { UCUUGGUCACCUGUAGCUU } \\
\text { UGUACAGGAUGUAUACGAU } \\
\text { AGACAUCGGGUGCAUCCAA }\end{array}$ & $\begin{array}{l}\text { AAGCUACAGGUGACCAAGA } \\
\text { AUCGUAUACAUCCUGUACA } \\
\text { UUGGAUGCACCCGAUGUCU }\end{array}$ \\
\hline $\mathrm{Ga}_{12}$ & UGACUUCGUUAUAAAGAAATT & UUUCUUUAUAACGAAGUCATG \\
\hline $\mathrm{Ga}_{13}$ & CCAUAAUCCUCUUCUUAAATT & UUUAAGAAGAGGAUUAUGGAG \\
\hline $\mathrm{Ga}_{\mathrm{q}}$ & GGUGGAUAGUAUUAUCCUATT & UAGGAUAAUACUAUCCACCAG \\
\hline $\begin{array}{l}\text { Sphingosine } \\
\text { kinase } 1\end{array}$ & CGAGCAGGUGACUAAUGAATT & UUCAUUAGUCACCUGCUCGTA \\
\hline
\end{tabular}

\section{SRE.L luciferase assay}

Astrocytes were cultured on 12-well plates and transfected with $500 \mathrm{ng}$ of SRE.L and $50 \mathrm{ng}$ of Renilla as an internal control using DharmaFECT-3 as described above. Following overnight incubation, cells were serumstarved for 18-24 h prior to S1P treatment for $8 \mathrm{~h}$. Cells were lysed, and luciferase activities were measured using the Dual-Luciferase Reporter Assay System (Promega).

\section{In vitro scratch injury model}

WT or $\mathrm{S1P}_{3} \mathrm{KO}$ astrocytes were cultured on six-well plates and grown to confluence followed by serum starvation for $18-24 \mathrm{~h}$. To stimulate astrogliosis and inflammation, plates were scratched with a $200-\mu \mathrm{L}$ pipette tip six times (three vertical and three horizontal) across the dish [47]. Cells were harvested and lysed after $1 \mathrm{~h}$ scratch for mRNA analysis or after $8 \mathrm{~h}$ for Western blotting as described below.

\section{q-PCR}

For gene expression analyses, RNA was extracted from astrocytes using an RNeasy kit (Invitrogen) [40]. Complementary DNA (cDNA) was synthesized with High-Capacity cDNA Reverse Transcription Kit (Applied Biosystems ABI) and real-time q-PCR performed with TaqMan Universal Master Mix II, with UNG (Applied Biosystems ABI). To analyze gene expression in mouse astrocytes treated with S1P or scratch wounding, gene-specific primers for COX-2, IL-6, VEGFa, $\mathrm{S} 1 \mathrm{P}_{1}, \mathrm{~S}_{1} \mathrm{P}_{2}, \mathrm{~S}_{1} \mathrm{P}_{3}$, Sphk1, and GAPDH (as an internal control) were used (Integrated DNA Technologies). $\mathrm{S}_{1} \mathrm{P}_{3} \mathrm{KO}$ astrocytes were analyzed for the levels of $\mathrm{S}_{1} \mathrm{P}_{1}$ and $\mathrm{S} \mathrm{P}_{2}$ and were found to have no significant compensatory changes (data not shown). Data were normalized to internal GAPDH, and fold change was determined according to a published protocol [48]. Values for comparison for a single gene across multiple samples was determined using cycle threshold (Ct) data fitted to a standard curve. For comparison of multiple transcripts in a single sample, then the 2 $-\Delta \Delta \mathrm{Ct}$ method was applied to the $\mathrm{Ct}$ value [48].

\section{Western blotting}

Astrocytes were lysed in RIPA buffer $(20 \mathrm{~mm}$ Tris, $250 \mathrm{~mm}$ $\mathrm{NaCl}, 3 \mathrm{~mm}$ EDTA, $3 \mathrm{~mm}$ EGTA, and $20 \mathrm{~mm} \beta$ glycerophosphate) supplemented with sodium vanadate, leupeptin, aprotinin, $p$-nitrophenyl phosphate, and phenylmethylsulfonyl fluoride. BCA analysis was performed using the Micro BCA Protein Assay Kit (ThermoFisher Scientific) to determine protein concentration. Equal amounts of protein $(10 \mu \mathrm{g})$ were loaded onto $4-12 \% 10$-well or 15-well SDS-PAGE gels (Invitrogen NuPage System). Gels were transferred to PVDF membranes (Millipore), and the resulting blot was probed with specific antibodies. The COX-2 antibody (Cayman \#160126) was used at 1:500 dilution, and the band running at $72 \mathrm{kDa}$ band was quantitated. The GAPDH antibody (Cell Signaling Technology \#2118) was used at 1:1000 dilution, and a band at $37 \mathrm{kDa}$ was quantitated. Rabbit secondary antibody was used at 1:4000 dilution. Fold changes were determined by densitometry and normalized to accompanying GAPDH blots.

\section{Statistical analysis}

Statistical differences were determined using Tukey's multicomparison analysis following one-way ANOVA with Prism software (GraphPad). $p<0.05$ was considered significant.

\section{Results}

$\mathrm{S} \mathrm{P}_{3}$ is highly expressed in astrocytes and mediates increases in COX-2 protein expression

We used q-PCR to compare directly the levels of mRNA expression for ${\mathrm{S} 1 \mathrm{P}_{1-3}}_{3}$ in the cultured mouse astrocytes used in the studies presented here. Relative expression levels for $\mathrm{S} 1 \mathrm{P}_{3}(4.7)>\mathrm{S}_{1} \mathrm{P}_{1}(1.6)>\mathrm{S}_{1} \mathrm{P}_{2}(0.7)$ mRNA were established using absolute quantitative-PCR (Fig. 1a). To examine S1P receptor subtype involvement in induction of the inflammatory gene COX-2, all three receptor subtypes were knocked down prior to treatment with S1P. Knockdown with $\mathrm{S}_{1} \mathrm{P}_{1}$ siRNA (78\% decrease in $\mathrm{S}_{1} \mathrm{P}_{1}$ mRNA) had no effect on COX-2 protein expression in cells stimulated for $6 \mathrm{~h}$ with S1P. Knockdown of $\mathrm{S}_{3} \mathrm{P}_{3}$ (80\%) significantly attenuated S1P-stimulated COX-2 expression, and the combination of $\mathrm{S}_{1} \mathrm{P}_{2}$ and $\mathrm{S}_{1} \mathrm{P}_{3}$ knockdown was most effective (Fig. 1b). Knockdown of $\mathrm{S}_{2} \mathrm{P}_{2}$ (83\%) diminished but did not significantly decrease S1Pinduced COX-2 protein expression nor did pretreatment with the selective ${\mathrm{S} 1 \mathrm{P}_{2}}_{2}$ antagonist JTE-013 (Fig. 1c). In contrast, SPM-354, a bitopic antagonist that has a 
significantly higher affinity for $\mathrm{S} \mathrm{P}_{3}$ than for $\mathrm{S}_{1} \mathrm{P}_{2}$ (1840fold) or $\mathrm{S}_{1} \mathrm{P}_{1}$ (30-fold) [45], decreased S1P-induced COX-2 expression by more than 70\% (Fig. 1d) further confirming the predominant role of $\mathrm{S}_{1} \mathrm{P}_{3}$ activation in COX-2 protein expression. The $\mathrm{S}_{1} \mathrm{P}_{2}$ and $\mathrm{S}_{1} \mathrm{P}_{3}$ receptor subtypes can serve redundant functions in regulation of RhoA and other downstream responses in some cell systems $[36,49]$ but our data indicates that $\mathrm{S1P}_{3}$ mRNA is most highly expressed in mouse astrocytes and plays the predominant role in mediating COX-2 protein expression in response to S1P.

\section{$\mathrm{S} \mathrm{P}_{3}$ is required for induction of inflammatory genes in astrocytes}

To provide further evidence that $\mathrm{S}_{1} \mathrm{P}_{3}$ is the receptor on astrocytes that is primarily responsible for the induction of COX 2 and other inflammatory genes, astrocytes were isolated from WT and $\mathrm{S}_{3} \mathrm{P}_{3} \mathrm{KO}$ mice. The ability of $\mathrm{S} 1 \mathrm{P}$ to increase inflammatory gene mRNA was examined at $1 \mathrm{~h}$ treatment since it was demonstrated that mRNA for IL-6 and COX-2 were significantly increased by S1P at this early time [40]. Deletion of $\mathrm{S} \mathrm{P}_{3}$ fully prevented
S1P-mediated increases in IL-6 (Fig. 2a) and VEGFa (Fig. 2b) mRNA. Induction of COX-2 mRNA (Fig. 2c) was markedly but not fully attenuated paralleling the changes in COX-2 protein expression shown in Fig. 1b which suggests some redundancy in $\mathrm{S}_{1} \mathrm{P}_{2}$ and $\mathrm{S}_{1} \mathrm{P}_{3}$ signaling to $\mathrm{COX} 2$ expression. Next, we used a recently generated $\mathrm{S}_{1} \mathrm{P}_{3}$ receptor allosteric agonist, CYM-51736, which is more specific than the previous $\mathrm{S}_{3} \mathrm{P}_{3}$ agonists $[50,51]$. CYM-51736 increased COX-2 protein in WT but not in $\mathrm{S} \mathrm{P}_{3} \mathrm{KO}$ astrocytes (Fig. 2d), consistent with its specificity and the ability of $\mathrm{S}_{3} \mathrm{P}_{3}$ activation to regulate COX-2 mRNA expression. Finally, we tested FTY720 (fingolimod), which acts as an agonist at both $\mathrm{S}_{1} \mathrm{P}_{1}$ and $\mathrm{S}_{1} \mathrm{P}_{3}$. FTY720 treatment increased COX-2 protein expression in WT but not in $\mathrm{S}_{3} \mathrm{P}_{3} \mathrm{KO}$ astrocytes (Fig. 2e), suggesting that its agonist actions at $\mathrm{S}_{3} \mathrm{P}_{3}$ induce astrocyte inflammatory genes.

\section{$\mathrm{S}_{1} \mathrm{P}_{3}$ signals through $\mathrm{Ga}_{12 / 13}$ and RhoA to induce gene expression}

The $\mathrm{G \alpha}_{12 / 13}$ proteins are the G-protein family members that most effectively couple GPCRs to RhoA exchange a

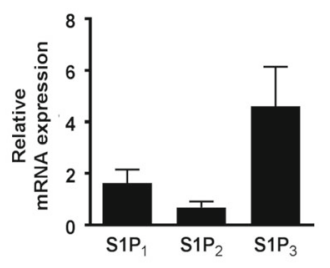

C
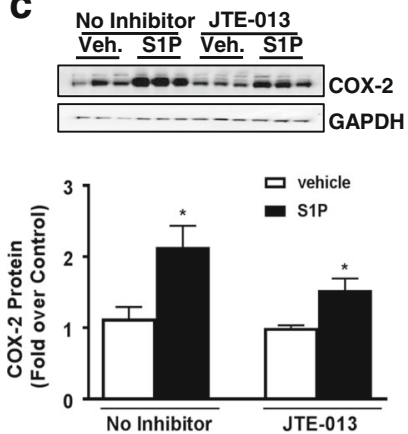

b

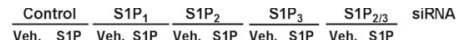

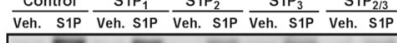
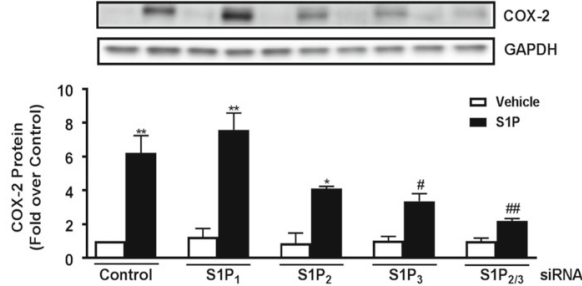

d
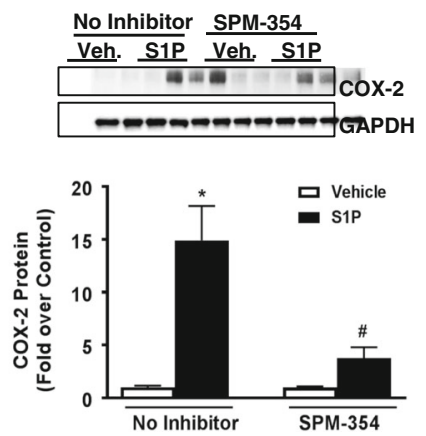

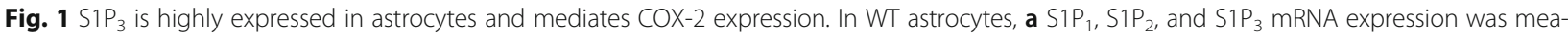
sured by absolute PCR. $\mathbf{b}$ Quantification and Western blot of COX-2 protein expression after S1P treatment $(0.5 \mu \mathrm{M}, 6 \mathrm{~h})$ following knockdown of $\mathrm{S}_{1} \mathrm{P}_{1}, \mathrm{~S}_{\mathrm{P}}, \mathrm{S}_{2} \mathrm{P}_{3}$, and $\mathrm{S} 1 \mathrm{P}_{2 / 3}$ with siRNA $(2 \mu \mathrm{M})$. Data shown are mean $\pm \mathrm{SEM}$ of values from three independent experiments run in triplicate. COX2 was normalized to GAPDH and expressed relative to control siRNA vehicle treated. ${ }^{*} p<0.05$ and ${ }^{* *} p<0.01$ between vehicle and S1P-treated groups and \#p<0.05 and \#\#p<0.01 between control siRNA S1P-treated and S1P receptor siRNA S1P-treated groups. c Quantification and Western blot of COX-2 expression after pretreatment with the S1P 2 antagonist JTE-013 for 30 min (1 $\mu \mathrm{M})$ followed by S1P treatment $(0.5 \mu \mathrm{M}, 6$ h). Data shown are mean \pm SEM of values from three independent samples. COX-2 was normalized to GAPDH and expressed relative to vehicle control. ${ }^{*} p<0.05$ between vehicle and S1P-treated groups. d Quantification and Western blot of COX-2 expression after pretreatment with the S1P 3 antagonist SPM-354 for $15 \mathrm{~min}(5 \mu \mathrm{M})$ followed by S1P treatment $(0.5 \mu \mathrm{M}, 6 \mathrm{~h})$. Data shown are mean \pm SEM of values from three independent experiments run in triplicate. COX-2 was normalized to GAPDH and expressed relative to vehicle control. ${ }^{*} p<0.05$ between vehicle and S1P-treated groups and \#p<0.05 between control S1P-treated and SPM-454/S1P-treated group 

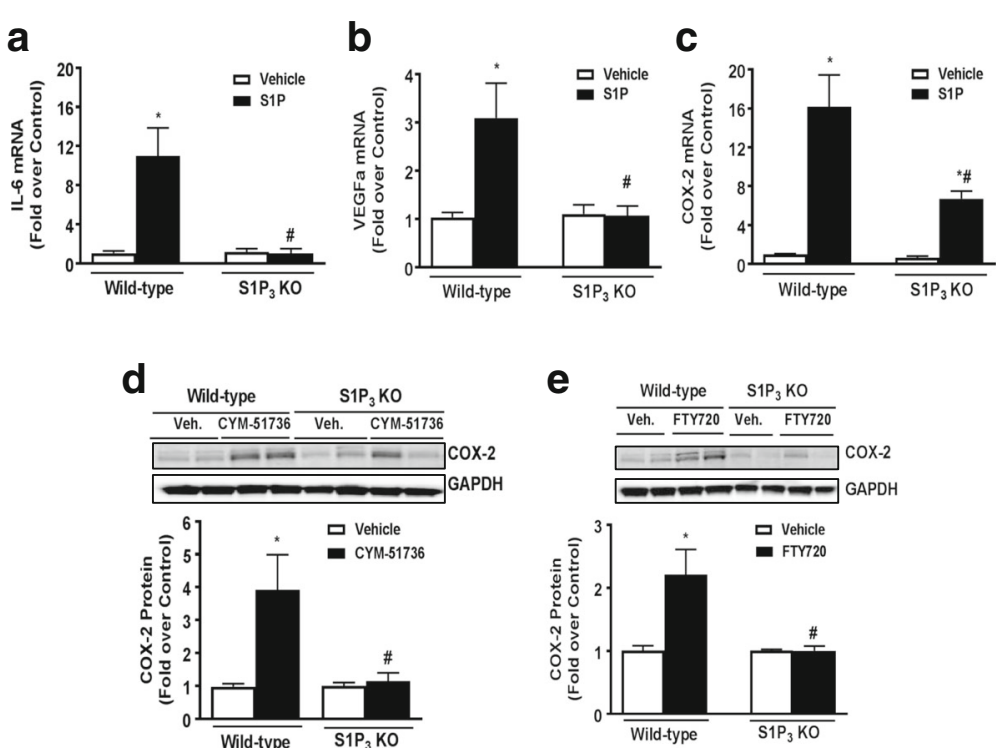

Fig. $2 \mathrm{~S}_{\mathrm{P}} \mathrm{P}_{3}$ is required for induction of inflammation in astrocytes. WT and S1P $\mathrm{P}$ KO astrocytes were treated with vehicle or S1P $(0.5 \mu \mathrm{M})$ for $1 \mathrm{~h}$, and IL-6 (a), VEGFa (b), and COX-2 (c) mRNA expression was measured by q-PCR. IL-6, VEGFa, and COX-2 were normalized to GAPDH, and fold increase expressed relative to the WT or KO vehicle treated. Data shown are mean \pm SEM of three independent experiments run in triplicate. ${ }^{*} p<0.01$ between vehicle and S1P-treated groups and \#p $<0.01$ between WT and KO S1P-treated groups. d Quantification and Western blot of COX-2 expression in WT and S1P ${ }_{3}$ KO astrocytes treated with CYM-51736 $(10 \mu \mathrm{M}, 6 \mathrm{~h})$. Data shown are mean \pm SEM of values from three independent experiments run in triplicate. COX-2 was normalized to GAPDH and expressed relative to the WT or KO vehicle treated. e Quantification and Western blot of COX-2 expression in FTY720treated $(100 \mathrm{nM}, 6 \mathrm{~h}) \mathrm{WT}$ and $\mathrm{S}_{1} \mathrm{P}_{3} \mathrm{KO}$ astrocytes. Data shown are mean $\pm \mathrm{SEM}$ of values from three independent experiments run in triplicate. COX-2 was normalized to GAPDH and expressed relative to the WT or KO vehicle treated. ${ }^{*} p<0.01$ between vehicle and treatment groups and $\# p<0.01$ between WT and KO treatment groups

factors and thus to activation of RhoA. To demonstrate that $\mathrm{S}_{1} \mathrm{P}_{3}$ activates inflammatory gene expression by signaling through $\mathrm{G \alpha}_{12 / 13}$, we used siRNAs to achieve combined knockdown of $\mathrm{G \alpha}_{12}$ and $\mathrm{G \alpha}_{13}$ (92\% decrease in $\mathrm{G \alpha}_{12}$ mRNA and $90 \%$ decrease in $\mathrm{G \alpha}_{13}$ mRNA). In addition, RhoA was functionally inhibited by pretreatment of cells with $\mathrm{C} 3$ exoenzyme. Both interventions significantly decreased S1P-mediated increases in COX2 protein (Fig. 3a, b). We further demonstrated that induction of COX-2, IL-6, and VEGFa mRNAs by S1P were attenuated by knockdown of $\mathrm{G \alpha}_{12}$ and $\mathrm{G \alpha}_{13}$ (Fig. 3c-e).

The SRE.L luciferase reporter gene contains a truncated TCF-independent binding site for serum response factor (SRF) and is widely used as a readout for activated RhoA, which regulates genes through SRF and its transcriptional co-activator MRTF-A [52, 53]. S1P markedly increased SRE.L luciferase activity (16 to 50-fold, depending on the experiment). The S1P response (shown as $100 \%$ in the averaged experiments in Fig. 4) was attenuated by functional blockade of Rho signaling with C3 treatment and by knockdown of $\mathrm{S}_{1} \mathrm{P}_{2}, \mathrm{~S}_{1} \mathrm{P}_{3}$, and $\mathrm{G \alpha}_{12 / 13}$, but not by knockdown of $\mathrm{S}_{1} \mathrm{P}_{1}$ or $\mathrm{G \alpha}_{\mathrm{q}}$. Inhibition of $\mathrm{G \alpha}_{\mathrm{i}}$ function by pretreatment with pertussis toxin (PTX) was also without effect on S1P-stimulated SRE.L activation. These data demonstrate $\mathrm{S}_{1} \mathrm{P}_{3}$ and $\mathrm{S}_{2} \mathrm{P}_{2}$ coupling to $\mathrm{G \alpha}_{12 / 13}$ to activate RhoA, which in turn regulates COX-2 and other inflammatory genes in astrocytes.

\section{$\mathrm{S}_{1} \mathrm{P}_{3}$ and Sphk1 are upregulated in response to in vitro wounding and mediate COX-2 expression}

To determine whether the signaling pathway delineated above could be activated under pathophysiological conditions, we used an in vitro scratch injury model to simulate localized inflammation of cultured astrocyte [47]. Within an hour after cells were scratched, $\mathrm{S}_{3} \mathrm{P}_{3}$ (but not $\mathrm{S}_{1} \mathrm{P}_{1}$ or $\mathrm{S}_{1} \mathrm{P}_{2}$ ) mRNA was increased relative to control unscratched cells (Fig. 5a) as was the mRNA level for sphingosine kinase 1 (Sphk1), the enzyme that catalyzes the synthesis of S1P (Fig. 5b) [54]. Our previous studies showed that injuring astrocytes increases COX-2 expression and that the media from scratched cells contains substances that contribute to this response [40]. To determine whether this localized inflammatory response could be mediated by the actions of S1P, formed from the elevated Sphk1 and acting on astrocyte $\mathrm{S}_{1} \mathrm{P}_{3}$, we repeated the scratch injury studies using $\mathrm{S}_{\mathrm{P}} \mathrm{P}_{3}$ $\mathrm{KO}$ astrocytes. The increase in COX-2 protein expression was lost, indicating that the ability of scratch to elicit this response requires $\mathrm{S}_{1} \mathrm{P}_{3}$ (Fig. 5c). We confirmed this further by comparing wild-type cells that were subject to scratch injury in the presence or absence of the 

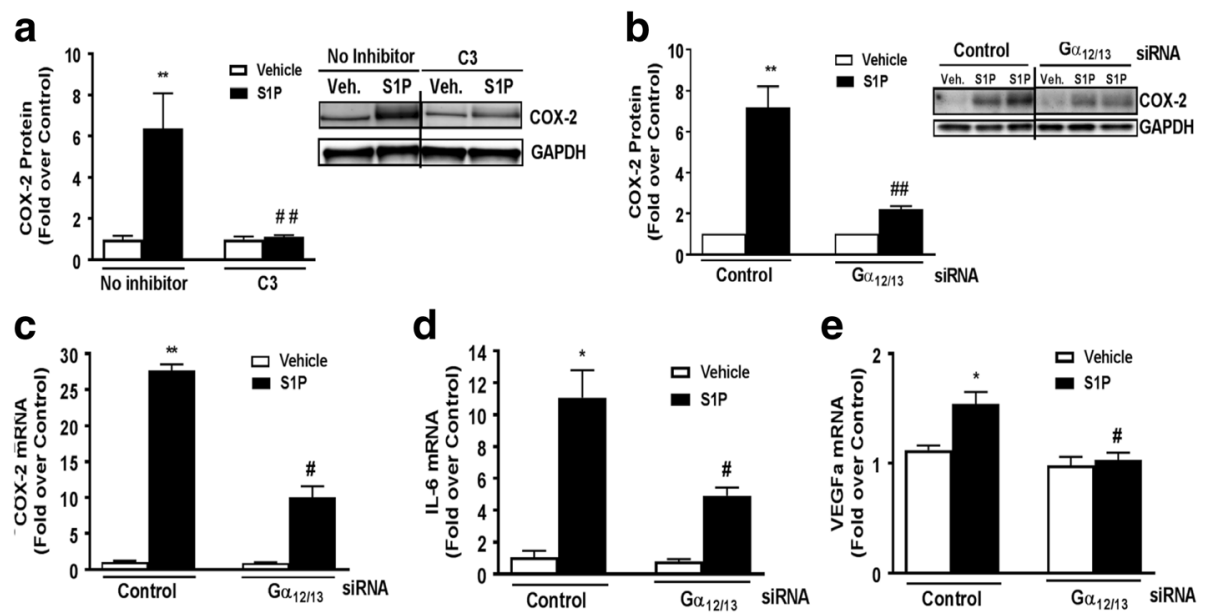

Fig. 3 S1P signals through $\mathrm{Ga}_{12 / 13}$ and RhoA to induce COX-2 expression. a COX-2 protein expression was measured in WT cells pretreated with C3 exoenzyme $(0.5 \mu \mathrm{g} / \mathrm{mL})$ for $4 \mathrm{~h}$ prior to vehicle or S1P $(0.5 \mu \mathrm{M})$ treatment for $6 \mathrm{~h}$. COX-2 was normalized to GAPDH and expressed relative to the averaged \pm inhibitor controls. Representative Western blot and data shown are mean \pm SEM from three independent experiments run in triplicate. The blot represents a single gel where unnecessary lanes have been removed. ${ }^{* *} p<0.01$ between vehicle and S1P-treated groups and \#\#p $<0.01$ between S1P-treated \pm inhibitor groups. b Quantification and Western blot of COX-2 protein levels after knockdown of Ga $a_{12 / 13}$ with siRNA ( $\left.2 \mu \mathrm{M}\right)$ followed by S1P treatment $(5 \mu \mathrm{M}, 6 \mathrm{~h})$. The blot represents a single gel where unnecessary lanes have been removed. Data shown are mean \pm SEM of values from four independent experiments run in triplicate. COX-2 was normalized to GAPDH and expressed relative to the siRNA control. mRNA expression levels of COX-2 (c), IL-6 (d), and VEGFa (e) were measured by q-PCR following knockdown of Ga $\mathrm{G}_{12 / 13}$ with siRNA (2 $\left.\mu \mathrm{M}\right)$ and S1P treatment $(0.5 \mu \mathrm{M}, 1 \mathrm{~h})$. Data shown are mean \pm SEM from three independent experiments run in triplicate. COX-2, IL-6, and VEGFa were normalized to GAPDH and fold increase expressed relative to the vehicle-treated control siRNA. ${ }^{*} p<0.05$ and ${ }^{* *} p<0.01$ between vehicle and S1P-treated groups and \#p<0.05 and \#\#p<0.01 between control and $\mathrm{Ga}_{12 / 13} \mathrm{~S} 1 \mathrm{P}$-treated groups

$\mathrm{S} 1 \mathrm{P}_{3}$ inhibitor SPM-354 used in Fig. 1d. Pharmacological blockade of $\mathrm{S}_{1} \mathrm{P}_{3}$, like genetic deletion of the receptor, prevented scratch-induced COX-2 expression (Fig. 5d). Finally, to test the importance of localized formation of S1P, we knocked down Sphk1 using siRNA (90\% reduction in Sphk1). Scratch injury failed to increase COX-2

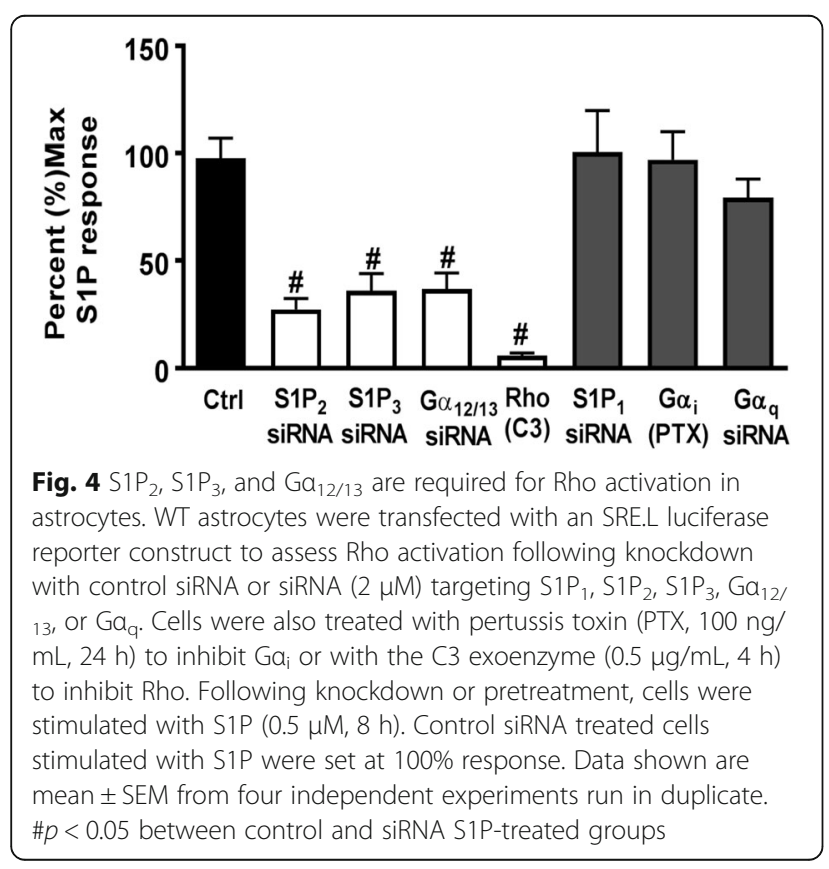

protein expression when Sphk1 was downregulated (Fig. 5e) implicating this enzyme, its product, and $\mathrm{S}_{3} \mathrm{P}_{3}$ activation in localized astrocyte COX-2 induction.

\section{Discussion}

Neuroinflammation, which underlies many neurodegenerative processes including those involved in Alzheimer's disease, Parkinson's disease, and MS, is increasingly recognized as a hallmark of CNS pathology [19, 20, 55-58]. Astrocytes were once considered as structural elements in the brain but subsequently emerged as functionally important for neuronal guidance, maintenance of the $\mathrm{BBB}$, and structural and metabolic support of neurons $[15,17,18]$. In addition, astrocytes, like microglia, are now known to contribute to neuroinflammation [14, 17, 19, 56, 59]. The lysophospholipid S1P regulates astrogliosis and inflammatory responses in the CNS; however, the role of the individual S1P receptor subtypes in these processes has not been clearly delineated $[23,30,31,33$, $34,60,61]$.

Astrocytes contribute to neuroinflammation by upregulating proinflammatory mediators such us IL-6, MCP1 , TNF- $\alpha$, iNOS, and COX-2 [15, 17, 40, 62]. Induction of COX-2 in astrocytes increases generation of reactive oxygen species (ROS), as well as formation of prostanoids that play a prominent role in inflammation, and thus further contribute to neuronal cell death and demyelination in diseases such as MS [20,56]. Moreover, 

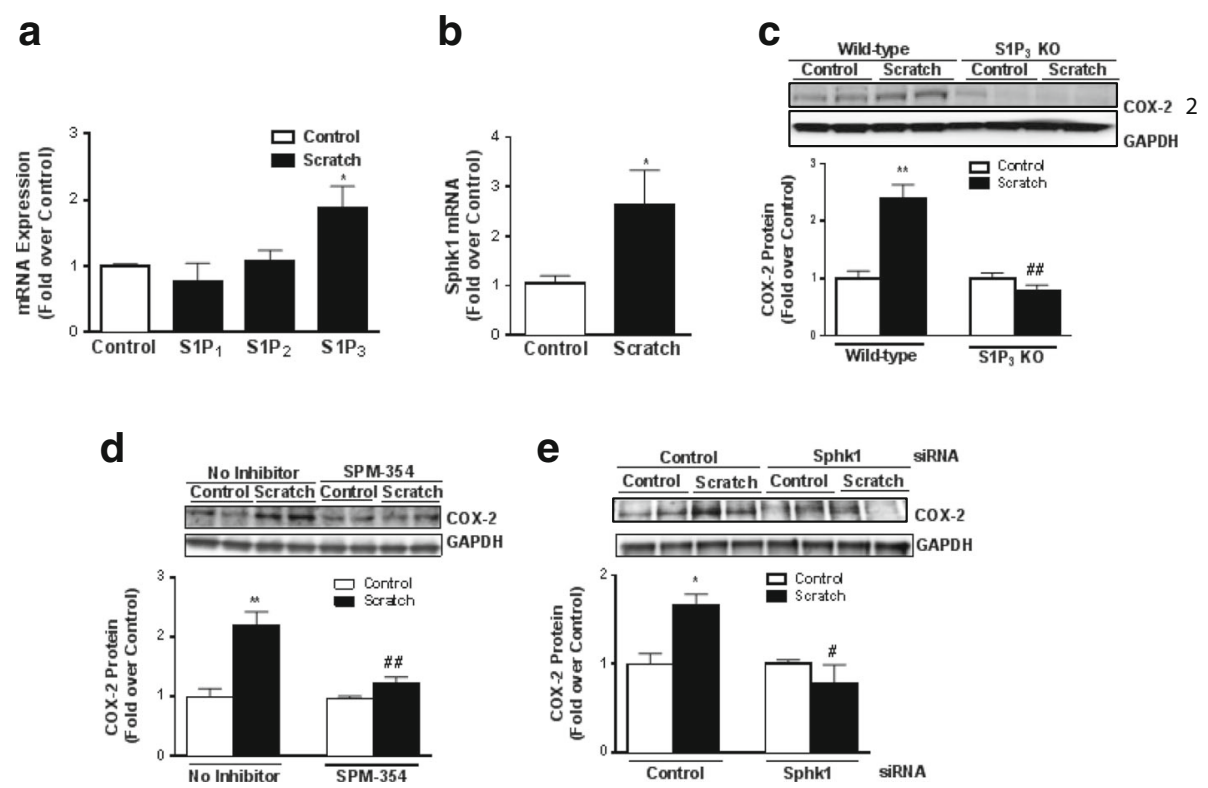

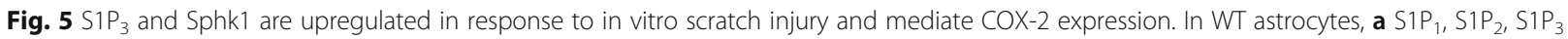
and $\mathbf{b}$ SphK1 mRNA expression were measured $1 \mathrm{~h}$ after scratch injury on culture plates. Data shown are mean \pm SEM from three independent experiments run in triplicate. Fold increase is relative to the scratch control for each receptor subtype or Spkh1. * $p<0.05$ between control and scratch-treated groups. COX-2 protein levels were measured after $8 \mathrm{~h}$ of scratch in c S1P 3 KO astrocytes or $\mathbf{d}$ WT astrocytes pretreated with SPM$354(5 \mu \mathrm{M}, 15 \mathrm{~min})$. COX-2 was normalized to GAPDH and expressed relative to the WT or KO controls or the \pm inhibitor controls. Data shown are mean \pm SEM from three independent experiments run in triplicate. e COX-2 protein levels were measured in WT astrocytes after knockdown of Sphk1 with siRNA $(2 \mu \mathrm{M})$ or control siRNA followed by scratch for $8 \mathrm{~h}$. COX-2 was normalized to GAPDH and expressed relative to the \pm siRNA controls. Data shown are mean \pm SEM from three independent experiments run in duplicate. ${ }^{*} p<0.05$ and ${ }^{* *} p<0.01$ between control and scratch-treated groups and \#p $<0.05$ and \#\#p $<0.01$ between scratch-treated groups of either WT and $\mathrm{KO}$, with or without inhibitor, or siRNA

astrocytes produce VEGF which plays a role in the breakdown of the blood-brain barrier, a step critical to the entry of pathogenic lymphocytes into the brain [63-67]. Our data demonstrate that an important mechanism for induction of inflammatory cytokines and cytotoxic mediators such as IL-6, COX-2, and VEGFa in astrocytes is through their exposure to $\mathrm{S} 1 \mathrm{P}$ and activation of $\mathrm{S}_{1} \mathrm{P}_{3}$.

Both $\mathrm{S}_{1} \mathrm{P}_{1}$ and $\mathrm{S}_{1} \mathrm{P}_{3}$ are expressed on astrocytes $[8,12]$ and are upregulated on reactive astrocytes that contribute to inflammation associated with CNS disease [32, 33, $35,61,68]$. In response to inflammatory stimuli or in CNS pathologies, Sphk1, an enzyme that generates S1P, is also increased in astroglial cells [23, 34, 35, 69, 70]. Our findings using siRNA and $\mathrm{S}_{3} \mathrm{P}_{3} \mathrm{KO}$ astrocytes demonstrate mechanistically that agonist binding to $\mathrm{S}_{1} \mathrm{P}_{3}$ signals to inflammatory responses through $\mathrm{S} \mathrm{P}_{3}$ coupling to $\mathrm{G \alpha}_{12 / 13}$ and activation of RhoA. We also show here, using an astrocyte scratch injury assay, that $\mathrm{S}_{1} \mathrm{P}_{3}$ and Sphk1 expression are increased by simulated inflammation and demonstrate by their knockout and downregulation, respectively, that they are involved in an autocrine signaling loop to increase COX-2 expression. While $\mathrm{S}_{2} \mathrm{P}_{2}$ could also signal through $\mathrm{G \alpha}_{12 / 13}$ and RhoA to contribute to COX-2 expression ([37, 71-73] and Fig. 4) and appears to serve this role when $\mathrm{S} \mathrm{P}_{3}$ is downregulated (Fig. 1b), the relatively low expression of this receptor subtype and its lack of upregulation in response to wounding suggests limited involvement in astrocyte inflammatory responses (Fig. 1c). Thus, it appears that $\mathrm{S}_{1} \mathrm{P}_{3}$, and its autocrine activation by $\mathrm{S} 1 \mathrm{P}$ generated through Sphk1, are poised to mediate astrocytic inflammatory responses that could contribute to the progression of CNS neuropathology.

S1P signaling in the CNS has important pathophysiological consequences [21, 28-30, 33-35, 40, 61, 74]. Much research has focused on $\mathrm{S}_{1} \mathrm{P}_{1}$ as the primary target for the MS drug FTY720 (fingolimod). While a well-recognized effect of fingolimod is to functionally antagonize $\mathrm{S}_{1} \mathrm{P}_{1}$ receptors on lymphocytes and thereby prevent their egress into the blood and access to the brain, $\mathrm{S}_{1} \mathrm{P}_{1}$ localized to astrocytes contributes significantly to the effects of this drug in an experimental model of MS [75]. The basis for also considering $\mathrm{S} \mathrm{P}_{3}$ signaling in MS is that this receptor subtype is upregulated in astrocytes during MS and in EAE and that it is a target for fingolimod [33, 61]. Notably, fingolimod causes transient bradycardia that appears, at least in the mouse, to be due to its agonist actions on $\mathrm{S}_{3} \mathrm{P}_{3}[24,25$, 76-78]. While it is clear that fingolimod downregulates $\mathrm{S} \mathrm{P}_{1}$, and thus acts as a functional antagonist, its ability 
to similarly downregulate and thus act as a functional antagonist of $\mathrm{S}_{1} \mathrm{P}_{3}$ is controversial $[61,77,79,80]$. A recent study demonstrated that continuous treatment with FTY20, initiated at the onset of disease in an EAE model, reduced $\mathrm{S}_{1} \mathrm{P}_{3}$ expression at day 22 [61]. While this indicates that $\mathrm{S}_{1} \mathrm{P}_{3}$ is downregulated by FTY720 treatment, this could reflect reversal of the disease process/inflammation (and its accompanying increases in $\mathrm{S}_{1} \mathrm{P}_{3}$ gene expression) rather than downregulation at the receptor level. Our data with FTY720 (like that examining bradycardia) demonstrate that FTY720 acts as an agonist, eliciting COX-2 induction, over a period of at least $6 \mathrm{~h}$. Our data further establish that it is $\mathrm{S} \mathrm{P}_{3^{-}}$ mediated RhoA signaling, not effects of $\mathrm{S}_{1} \mathrm{P}_{1}$ and $\mathrm{G \alpha}_{\mathrm{i}}$, that lead to maladaptive astrocyte inflammation. Thus, agonism at astrocyte $\mathrm{S} \mathrm{P}_{3}$ by fingolimod or other drugs could contribute to neuroinflammation and worsen disease progression, particularly when $\mathrm{S}_{1} \mathrm{P}_{3}$ are upregulated and S1P availability increased through activation of sphingosine kinase. Further studies using $\mathrm{S}_{1 / 3}$ double knockout mice are ongoing and should indicate whether blocking $\mathrm{S}_{1} \mathrm{P}_{3}$, in addition to $\mathrm{S}_{1} \mathrm{P}_{1}$, would have additional therapeutic benefit.

The importance of $\mathrm{S}_{1} \mathrm{P}_{3}$ and RhoA signaling in CNS disease could be logically extended to consideration of any of the myriad GPCRs found on astrocytes [32] that couple to RhoA signaling. We and others have shown that PAR1, the receptor for thrombin, couples through RhoA to mediate proliferation and inflammatory responses in astrocytes [39, 40]. Thrombin is also increased in the injured brain [81, 82], and an antagonist of protease activated receptor 1 (PAR1) reduces clinical symptoms in EAE mice [83]. Thus, the evidence that $\mathrm{S} \mathrm{P}_{3}$ and other GPCRs that stimulate RhoA can contribute to sustained inflammatory responses suggests this pathway as a critical target for blocking neuroinflammation in MS and other CNS diseases.

\section{Conclusions}

Our findings demonstrate that $\mathrm{S} \mathrm{P}_{3}$ and Sphk1 are mediators of inflammatory signaling and are upregulated in astrocytes in response to injury. $\mathrm{S}_{1} \mathrm{P}_{3}$ couples to $\mathrm{G \alpha}_{12 / 13}$ and activated RhoA to induce COX-2, IL-6, and VEGFa mRNA as well as COX-2 protein expression in astrocytes. The data suggest that blocking $\mathrm{S}_{1} \mathrm{P}_{3}$, as well as the clinically relevant $\mathrm{S}_{1} \mathrm{P}_{1}$, could have therapeutic benefit for limiting CNS inflammatory disease progression.

\section{Abbreviations}

BBB: Blood-brain barrier; CNS: Central nervous system; COX-

2: Cyclooxygenase 2; EAE: Experimental Autoimmune Encephalomyelitis; GFAP: Glial fibrillary acidic protein; GPCR: G protein-coupled receptor; IL6: Interleukin 6; KO: Knockout; MS: Multiple Sclerosis; NF-KB: Nuclear factor kappa B; PAR1: Protease activated receptor 1; PTX: pertussis toxin; qPCR: Quantitative-PCR; S1P: Sphingosine 1-phosphate, S1P 1 , Sphingosine 1phosphate receptor $1 ; \mathrm{S}_{1} \mathrm{P}_{2}$ : Sphingosine 1-phosphate receptor 2 i

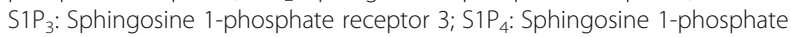

receptor 4; S1P : Sphingosine 1-phosphate receptor 5; Sphk1: Sphingosine kinase-1; VEGFa: Vascular Endothelial Growth Factor A; WT: Wild-type

\section{Acknowledgements}

We thank Melissa S. Barlow for her capable assistance with the animal breeding and genotyping and Jeffery M. Smith for the technical assistance.

\section{Funding}

This work was supported by National Institutes of Health Grants T32GM007752 (to S.S.D.), HL114949 (to N.H.P.), MH084512 (to H.R.), DA019674 (to J.C.), and HL028143 and GM36927 (to J.H.B.).

\section{Availability of data and materials}

Not applicable

\section{Authors' contributions}

SSD, NHP, and JHB designed of the study, carried out the experiments, and participated in the data analysis and manuscript preparation. JC and HR contributed to the data analysis and interpretation of the results. All authors reviewed the results and approved the final version of the manuscript.

\section{Competing interests}

The authors declare that they have no competing interests.

\section{Consent for publication}

Not applicable

\section{Ethics approval}

All procedures were performed in accordance with NIH Guide and Care and Use of Laboratory Animals and approved by the Institutional Animal Care and Use Committee at the University of California San Diego.

\section{Publisher's Note}

Springer Nature remains neutral with regard to jurisdictional claims in published maps and institutional affiliations.

\section{Author details}

${ }^{1}$ Department of Pharmacology, School of Medicine, University of California San Diego, 9500 Gilman Drive, Biomedical Sciences Building Room 3024, La Jolla, CA 92093-0636, USA. ${ }^{2}$ Sanford Burnham Prebys Medical Discovery Institute, La Jolla, CA 92037, USA. ${ }^{3}$ Department of Chemical Physiology, The Scripps Research Institute, La Jolla, CA 92037, USA.

Received: 1 September 2016 Accepted: 17 May 2017

Published online: 02 June 2017

\section{References}

1. Camerer E, Regard JB, Cornelissen I, Srinivasan Y, Duong DN, Palmer D, Pham TH, Wong JS, Pappu R, Coughlin SR. Sphingosine-1-phosphate in the plasma compartment regulates basal and inflammation-induced vascular leak in mice. J Clin Invest. 2009:119:1871-9.

2. Anelli $V$, Bassi $R$, Tettamanti G, Viani P, Riboni L. Extracellular release of newly synthesized sphingosine-1-phosphate by cerebellar granule cells and astrocytes. J Neurochem. 2005:92:1204-15.

3. Pappu R, Schwab SR, Cornelissen I, Pereira JP, Regard JB, Xu Y, Camerer E, Zheng YW, Huang Y, Cyster JG, Coughlin SR. Promotion of lymphocyte egress into blood and lymph by distinct sources of sphingosine-1phosphate. Science. 2007:316:295-8.

4. Yatomi Y, Ohmori T, Rile G, Kazama F, Okamoto H, Sano T, Satoh K, Kume S, Tigyi G, Igarashi Y, Ozaki Y. Sphingosine 1-phosphate as a major bioactive lysophospholipid that is released from platelets and interacts with endothelial cells. Blood. 2000;96:3431-8.

5. Yatomi Y, Igarashi Y, Yang L, Hisano N, Qi R, Asazuma N, Satoh K, Ozaki Y, Kume S. Sphingosine 1-phosphate, a bioactive sphingolipid abundantly stored in platelets, is a normal constituent of human plasma and serum. J Biochem. 1997;121:969-73.

6. Ishii I, Fukushima N, Ye X, Chun J. Lysophospholipid receptors: signaling and biology. Annu Rev Biochem. 2004;73:321-54.

7. Kihara Y, Maceyka M, Spiegel S, Chun J. Lysophospholipid receptor nomenclature review: IUPHAR Review 8. Br J Pharmacol. 2014;171:3575-94. 
8. Rao TS, Lariosa-Willingham KD, Lin FF, Palfreyman EL, Yu N, Chun J, Webb M. Pharmacological characterization of lysophospholipid receptor signal transduction pathways in rat cerebrocortical astrocytes. Brain Res. 2003:990:182-94.

9. Tham CS, Lin FF, Rao TS, Yu N, Webb M. Microglial activation state and lysophospholipid acid receptor expression. Int J Dev Neurosci. 2003;21: 431-43.

10. Toman RE, Payne SG, Watterson KR, Maceyka M, Lee NH, Milstien S, Bigbee JW, Spiegel S. Differential transactivation of sphingosine-1phosphate receptors modulates NGF-induced neurite extension. J Cell Biol. 2004;166:381-92.

11. Yu N, Lariosa-Willingham KD, Lin FF, Webb M, Rao TS. Characterization of lysophosphatidic acid and sphingosine-1-phosphate-mediated signal transduction in rat cortical oligodendrocytes. Glia. 2004;45:17-27.

12. Zhang Y, Chen K, Sloan SA, Bennett ML, Scholze AR, O'Keeffe S, Phatnani HP, Guarnieri P, Caneda C, Ruderisch N, Deng S, Liddelow SA, Zhang C, Daneman R, Maniatis T, Barres BA, Wu JQ. An RNA-sequencing transcriptome and splicing database of glia, neurons, and vascular cells of the cerebral cortex. J Neurosci. 2014:34:11929-47.

13. Choi JW, Chun J. Lysophospholipids and their receptors in the central nervous system. Biochim Biophys Acta. 2013;1:20-32.

14. Hamby ME, Sofroniew MV. Reactive astrocytes as therapeutic targets for CNS disorders. Neurotherapeutics. 2010;7:494-506.

15. Ridet JL, Malhotra SK, Privat A, Gage FH. Reactive astrocytes: cellular and molecular cues to biological function. Trends Neurosci. 1997;20:570-7.

16. Sofroniew MV. Molecular dissection of reactive astrogliosis and glial scar formation. Trends Neurosci. 2009;32:638-47.

17. Sofroniew MV. Multiple roles for astrocytes as effectors of cytokines and inflammatory mediators. Neuroscientist. 2014;20:160-72.

18. Sofroniew MV, Vinters HV. Astrocytes: biology and pathology. Acta Neuropathol. 2010;119:7-35.

19. Miljkovic D, Timotijevic G, Mostarica Stojkovic M. Astrocytes in the tempest of multiple sclerosis. FEBS Lett. 2011;585:3781-8.

20. Williams A, Piaton G, Lubetzki C. Astrocytes-friends or foes in multiple sclerosis? Glia. 2007;55:1300-12.

21. Sorensen SD, Nicole O, Peavy RD, Montoya LM, Lee CJ, Murphy TJ, Traynelis SF, Hepler JR. Common signaling pathways link activation of murine PAR-1, LPA, and S1P receptors to proliferation of astrocytes. Mol Pharmacol. 2003; 64:1199-209.

22. Pebay A, Toutant M, Premont J, Calvo CF, Venance L, Cordier J, Glowinski J, Tence M. Sphingosine-1-phosphate induces proliferation of astrocytes: regulation by intracellular signalling cascades. Eur J Neurosci. 2001;13:2067-76.

23. Moon E, Han JE, Jeon S, Ryu JH, Choi JW, Chun J. Exogenous S1P exposure potentiates ischemic stroke damage that is reduced possibly by inhibiting S1P receptor signaling. Mediators Inflamm. 2015;2015:492659.

24. Cohen JA, Barkhof F, Comi G, Hartung HP, Khatri BO, Montalban X, Pelletie J, Capra R, Gallo P, Izquierdo G, Tiel-Wilck K, de Vera A, Jin J, Stites T, Wu S, Aradhye $\mathrm{S}$, Kappos L. Oral fingolimod or intramuscular interferon for relapsing multiple sclerosis. N Engl J Med. 2010;362:402-15.

25. Kappos L, Radue EW, O'Connor P, Polman C, Hohlfeld R, Calabresi P, Selmaj K, Agoropoulou C, Leyk M, Zhang-Auberson L, Burtin P. A placebocontrolled trial of oral fingolimod in relapsing multiple sclerosis. N Engl J Med. 2010;362:387-401.

26. Cohen JA, Chun J. Mechanisms of fingolimod's efficacy and adverse effects in multiple sclerosis. Ann Neurol. 2011;69:759-77.

27. Kihara Y, Mizuno H, Chun J. Lysophospholipid receptors in drug discovery. Exp Cell Res. 2015;333:171-7.

28. Brinkmann V, Lynch KR. FTY720: targeting G-protein-coupled receptors for sphingosine 1-phosphate in transplantation and autoimmunity. Curr Opin Immunol. 2002;14:569-75.

29. Mandala S, Hajdu R, Bergstrom J, Quackenbush E, Xie J, Milligan J, Thornton R, Shei GJ, Card D, Keohane C, Rosenbach M, Hale J, Lynch CL, Rupprecht K, Parsons W, Rosen H. Alteration of lymphocyte trafficking by sphingosine-1phosphate receptor agonists. Science. 2002;296:346-9.

30. Choi JW, Gardell SE, Herr DR, Rivera R, Lee CW, Noguchi K, Teo ST, Yung YC Lu M, Kennedy G, Chun J. FTY720 (fingolimod) efficacy in an animal model of multiple sclerosis requires astrocyte sphingosine 1-phosphate receptor 1 (S1P1) modulation. Proc Natl Acad Sci U S A. 2011;108:751-6.

31. Mullershausen F, Craveiro LM, Shin Y, Cortes-Cros M, Bassilana F, Osinde M, Wishart WL, Guerini D, Thallmair M, Schwab ME, Sivasankaran R, Seuwen K,
Dev KK. Phosphorylated FTY720 promotes astrocyte migration through sphingosine-1-phosphate receptors. J Neurochem. 2007:102:1151-61.

32. Hamby ME, Coppola G, Ao Y, Geschwind DH, Khakh BS, Sofroniew MV. Inflammatory mediators alter the astrocyte transcriptome and calcium signaling elicited by multiple G-protein-coupled receptors. J Neurosci. 2012; 32:14489-510

33. Van Doorn R, Van Horssen J, Verzijl D, Witte M, Ronken E, Van Het Hof B, Lakeman K, Dijkstra CD, Van Der Valk P, Reijerkerk A, Alewijnse AE, Peters SL, De Vries HE. Sphingosine 1-phosphate receptor 1 and 3 are upregulated in multiple sclerosis lesions. Glia. 2010;58:1465-76.

34. Fischer I, Alliod C, Martinier N, Newcombe J, Brana C, Pouly S. Sphingosine kinase 1 and sphingosine 1-phosphate receptor 3 are functionally upregulated on astrocytes under pro-inflammatory conditions. PLoS One. 2011;6:e23905.

35. Wu YP, Mizugishi K, Bektas M, Sandhoff R, Proia RL. Sphingosine kinase 1/ S1P receptor signaling axis controls glial proliferation in mice with Sandhoff disease. Hum Mol Genet. 2008;17:2257-64

36. Ishii I, Ye X, Friedman B, Kawamura S, Contos JJ, Kingsbury MA, Yang AH, Zhang G, Brown JH, Chun J. Marked perinatal lethality and cellular signaling deficits in mice null for the two sphingosine 1-phosphate (S1P) receptors, S1P(2)/LP(B2)/EDG-5 and S1P(3)/LP(B3)/EDG-3. J Biol Chem. 2002;277:25152-9.

37. Siehler S, Manning DR. Pathways of transduction engaged by sphingosine 1-phosphate through G protein-coupled receptors. Biochim Biophys Acta. 2002;1582:94-9

38. Mutoh T, Rivera R, Chun J. Insights into the pharmacological relevance of lysophospholipid receptors. Br J Pharmacol. 2012;165:829-44.

39. Dusaban SS, Kunkel MT, Smrcka AV, Brown JH. Thrombin promotes sustained signaling and inflammatory gene expression through the CDC25 and Ras-associating domains of phospholipase C-epsilon. J Biol Chem. 2015:44:26776-83

40. Dusaban SS, Purcell NH, Rockenstein E, Masliah E, Cho MK, Smrcka AV, Brown JH. Phospholipase C epsilon links $\mathrm{G}$ protein-coupled receptor activation to inflammatory astrocytic responses. Proc Natl Acad Sci U S A. 2013:110:3609-14.

41. Post GR, Collins LR, Kennedy ED, Moskowitz SA, Aragay AM, Goldstein D, Brown JH. Coupling of the thrombin receptor to G12 may account for selective effects of thrombin on gene expression and DNA synthesis in 1321N1 astrocytoma cells. Mol Biol Cell. 1996;7:1679-90.

42. Walsh CT, Radeff-Huang J, Matteo R, Hsiao A, Subramaniam S, Stupack D, Brown JH. Thrombin receptor and RhoA mediate cell proliferation through integrins and cysteine-rich protein 61. FASEB J. 2008;22:4011-21.

43. Yu OM, Miyamoto S, Brown JH. Myocardin-related transcription factor a and yes-associated protein exert dual control in $\mathrm{G}$ protein-coupled receptorand RhoA-mediated transcriptional regulation and cell proliferation. Mol Cell Biol. 2015:36:39-49.

44. Citro S, Malik S, Oestreich EA, Radeff-Huang J, Kelley GG, Smrcka AV, Brown $J$ H. Phospholipase Cepsilon is a nexus for Rho and Rap-mediated G proteincoupled receptor-induced astrocyte proliferation. Proc Natl Acad Sci U S A. 2007:104:15543-8

45. Sanna MG, Vincent KP, Repetto E, Nguyen N, Brown SJ, Abgaryan L, Riley SW, Leaf NB, Cahalan SM, Kiosses WB, Kohno Y, Brown JH, McCulloch AD, Rosen H, Gonzalez-Cabrera PJ. Bitopic sphingosine 1-phosphate receptor 3 (S1P3) antagonist rescue from complete heart block: pharmacological and genetic evidence for direct S1P3 regulation of mouse cardiac conduction. Mol Pharmacol. 2016:89:176-86.

46. Ishii I, Friedman B, Ye X, Kawamura S, McGiffert C, Contos JJ, Kingsbury MA, Zhang G, Brown JH, Chun J. Selective loss of sphingosine 1-phosphate signaling with no obvious phenotypic abnormality in mice lacking its $G$ protein-coupled receptor, LP(B3)/EDG-3. J Biol Chem. 2001;276:33697-704.

47. Pan $H$, Wang $H$, Wang $X$, Zhu L, Mao L. The absence of Nrf2 enhances NFkappaB-dependent inflammation following scratch injury in mouse primary cultured astrocytes. Mediators Inflamm. 2012;2012:217580.

48. Schmittgen TD, Livak KJ. Analyzing real-time PCR data by the comparative C(T) method. Nat Protoc. 2008:3:1101-8.

49. Means CK, Xiao CY, Li Z, Zhang T, Omens JH, Ishii I, Chun J, Brown JH. Sphingosine 1-phosphate S1P2 and S1P3 receptor-mediated Akt activation protects against in vivo myocardial ischemia-reperfusion injury. Am J Physiol Heart Circ Physiol. 2007;292:H2944-51.

50. Jo E, Bhhatarai B, Repetto E, Guerrero M, Riley S, Brown SJ, Kohno Y, Roberts E, Schurer SC, Rosen H. Novel selective allosteric and bitopic ligands for the S1P(3) receptor. ACS Chem Biol. 2012;7:1975-83. 
51. Guerrero M, Poddutoori R, Urbano M, Peng X, Spicer TP, Chase PS, Hodder PS, Schaeffer MT, Brown S, Rosen H, Roberts E. Discovery, design and synthesis of a selective S1P(3) receptor allosteric agonist. Bioorg Med Chem Lett. 2013;23:6346-9.

52. Cen B, Selvaraj A, Burgess RC, Hitzler JK, Ma Z, Morris SW, Prywes R. Megakaryoblastic leukemia 1, a potent transcriptional coactivator for serum response factor (SRF), is required for serum induction of SRF target genes. Mol Cell Biol. 2003;23:6597-608.

53. Miralles F, Posern G, Zaromytidou Al, Treisman R. Actin dynamics control SRF activity by regulation of its coactivator MAL. Cell. 2003;113:329-42.

54. Kohama T, Olivera A, Edsall L, Nagiec MM, Dickson R, Spiegel S. Molecular cloning and functional characterization of murine sphingosine kinase. J Biol Chem. 1998;273:23722-8.

55. Ellwardt E, Zipp F. Molecular mechanisms linking neuroinflammation and neurodegeneration in MS. Exp Neurol. 2014;262 Pt A:8-17.

56. Glass CK, Saijo K, Winner B, Marchetto MC, Gage FH. Mechanisms underlying inflammation in neurodegeneration. Cell. 2010;140:918-34

57. Heneka MT, O'Banion MK, Terwel D, Kummer MP. Neuroinflammatory processes in Alzheimer's disease. J Neural Transm. 2010;117:919-47.

58. Minghetti L. Role of COX-2 in inflammatory and degenerative brain diseases. Subcell Biochem. 2007:42:127-41.

59. Sofroniew MV. Astrocyte barriers to neurotoxic inflammation. Nat Rev Neurosci. 2015;16:249-63.

60. Hoffmann FS, Hofereiter J, Rubsamen H, Melms J, Schwarz S, Faber H, Weber P, Putz B, Loleit V, Weber F, Hohlfeld R, Meinl E, Krumbholz M. Fingolimod induces neuroprotective factors in human astrocytes. J Neuroinflammation. 2015;12:184.

61. Colombo E, Di Dario M, Capitolo E, Chaabane L, Newcombe J, Martino G, Farina C. Fingolimod may support neuroprotection via blockade of astrocyte nitric oxide. Ann Neurol. 2014;76:325-37.

62. Burgos M, Fradejas N, Calvo S, Kang SU, Tranque P, Lubec G. A proteomic analysis of PKCepsilon targets in astrocytes: implications for astrogliosis. Amino Acids. 2011;40:641-51.

63. Schachtrup C, Ryu JK, Helmrick MJ, Vagena E, Galanakis DK, Degen JL, Margolis RU, Akassoglou K. Fibrinogen triggers astrocyte scar formation by promoting the availability of active TGF-beta after vascular damage. J Neurosci. 2010;30:5843-54.

64. Argaw AT, Asp L, Zhang J, Navrazhina K, Pham T, Mariani JN, Mahase S, Dutta DJ, Seto J, Kramer EG, Ferrara N, Sofroniew MV, John GR. Astrocytederived VEGF-A drives blood-brain barrier disruption in CNS inflammatory disease. J Clin Invest. 2012;7:2454-68.

65. Haseloff RF, Blasig IE, Bauer HC, Bauer $H$. In search of the astrocytic factor(s) modulating blood-brain barrier functions in brain capillary endothelial cells in vitro. Cell Mol Neurobiol. 2005;25:25-39.

66. Abbott NJ, Ronnback L, Hansson E. Astrocyte-endothelial interactions at the blood-brain barrier. Nat Rev Neurosci. 2006;7:41-53.

67. Baeten KM, Akassoglou K. Extracellular matrix and matrix receptors in bloodbrain barrier formation and stroke. Dev Neurobiol. 2011;71:1018-39.

68. Garris CS, Wu L, Acharya S, Arac A, Blaho VA, Huang Y, Moon BS, Axtell RC, Ho PP, Steinberg GK, Lewis DB, Sobel RA, Han DK, Steinman L, Snyder MP, Hla T, Han MH. Defective sphingosine 1-phosphate receptor 1 (S1P1) phosphorylation exacerbates TH17-mediated autoimmune neuroinflammation. Nat Immunol. 2013;14:1166-72.

69. Paugh BS, Bryan L, Paugh SW, Wilczynska KM, Alvarez SM, Singh SK, Kapitonov D, Rokita H, Wright S, Griswold-Prenner I, Milstien S, Spiegel S, Kordula T. Interleukin-1 regulates the expression of sphingosine kinase 1 in glioblastoma cells. J Biol Chem. 2009:284:3408-17.

70. Nayak D, Huo Y, Kwang WX, Pushparaj PN, Kumar SD, Ling EA, Dheen ST. Sphingosine kinase 1 regulates the expression of proinflammatory cytokines and nitric oxide in activated microglia. Neuroscience. 2010;166:132-44.

71. Volzke A, Koch A, Meyer Zu Heringdorf D, Huwiler A, Pfeilschifter J. Sphingosine 1-phosphate (SIP) induces COX-2 expression and PGE2 formation via S1P receptor 2 in renal mesangial cells. Biochim Biophys Acta. 1841;2014:11-21.

72. Sobel K, Monnier L, Menyhart K, Bolinger M, Studer R, Nayler O, Gatfield J. FTY720 phosphate activates sphingosine-1-phosphate receptor 2 and selectively couples to Galpha12/13/Rho/ROCK to induce myofibroblast contraction. Mol Pharmacol. 2015;87:916-27.

73. Skoura A, Sanchez T, Claffey K, Mandala SM, Proia RL, Hla T. Essential role of sphingosine 1-phosphate receptor 2 in pathological angiogenesis of the mouse retina. J Clin Invest. 2007;117:2506-16.
74. Bryan L, Kordula T, Spiegel S, Milstien S. Regulation and functions of sphingosine kinases in the brain. Biochim Biophys Acta. 2008;1781:459-66.

75. Groves A, Kihara Y, Chun J. Fingolimod: direct CNS effects of sphingosine 1phosphate (S1P) receptor modulation and implications in multiple sclerosis therapy. J Neurol Sci. 2013;328:9-18.

76. Forrest M, Sun SY, Hajdu R, Bergstrom J, Card D, Doherty G, Hale J, Keohane C, Meyers C, Milligan J, Mills S, Nomura N, Rosen H, Rosenbach M, Shei GJ, Singer II, Tian M, West S, White V, Xie J, Proia RL, Mandala S. Immune cell regulation and cardiovascular effects of sphingosine 1-phosphate receptor agonists in rodents are mediated via distinct receptor subtypes. J Pharmacol Exp Ther. 2004;309:758-68.

77. Brinkmann V, Billich A, Baumruker T, Heining P, Schmouder R, Francis G, Aradhye S, Burtin P. Fingolimod (FTY720): discovery and development of an oral drug to treat multiple sclerosis. Nat Rev Drug Discov. 2010;9:883-97.

78. Sanna MG, Liao J, Jo E, Alfonso C, Ahn MY, Peterson MS, Webb B, Lefebvre S, Chun J, Gray N, Rosen H. Sphingosine 1-phosphate (S1P) receptor subtypes S1P1 and S1P3, respectively, regulate lymphocyte recirculation and heart rate. J Biol Chem. 2004;279:13839-48.

79. Sensken SC, Staubert C, Keul P, Levkau B, Schoneberg T, Graler MH. Selective activation of $\mathrm{G}$ alpha i mediated signalling of S1P3 by FTY720phosphate. Cell Signal. 2008;20:1125-33.

80. Chun J, Brinkmann V. A mechanistically novel, first oral therapy for multiple sclerosis: the development of fingolimod (FTY720, Gilenya). Discov Med. 2011;12:213-28.

81. Nicole O, Goldshmidt A, Hamill CE, Sorensen SD, Sastre A, Lyuboslavsky P, Hepler JR, McKeon RJ, Traynelis SF. Activation of protease-activated receptor-1 triggers astrogliosis after brain injury. J Neurosci. 2005;25:4319-29.

82. Davalos D, Baeten KM, Whitney MA, Mullins ES, Friedman B, Olson ES, Ryu JK, Smirnoff DS, Petersen MA, Bedard C, Degen JL, Tsien RY, Akassoglou K. Early detection of thrombin activity in neuroinflammatory disease. Ann Neurol. 2014;75:303-8.

83. Kim HN, Kim YR, Ahn SM, Lee SK, Shin HK, Choi BT. Protease activated receptor-1 antagonist ameliorates the clinical symptoms of experimental autoimmune encephalomyelitis via inhibiting breakdown of blood-brain barrier. J Neurochem. 2015;135:577-88.

\section{Submit your next manuscript to BioMed Central and we will help you at every step:}

- We accept pre-submission inquiries

- Our selector tool helps you to find the most relevant journal

- We provide round the clock customer support

- Convenient online submission

- Thorough peer review

- Inclusion in PubMed and all major indexing services

- Maximum visibility for your research

Submit your manuscript at www.biomedcentral.com/submit
Biomed Central 